\title{
UKURAN PERUSAHAAN STRUKTUR MODAL DAN NILAI PERUSAHAAAN
}

\author{
Heince R.N. Wokas \\ (Email : heincewokas@gmail.com)
}

\begin{abstract}
The objective of this study is to find and to test the effect of firm size, capital structure, to firm value. The data for this study is secondary and taken in period of 2009 till 2011. The background of this study is based on inconsistency between fir size and capital structure to firm value. The study is using 22 listed companies in Indonesia Stock Exchange. This study is conducting path analysis for hypothesis testing.

The result of analysis is showing that firm size is not affecting the capital structure. Because market consideration on entity is to see the performance of entity to empower their internal funding rather than its size. This study is showing the significance relationship between capital structure and firm value of manufacturer companies in Indonesia.
\end{abstract}

\section{Latar Belakang Masalah}

Modigliani - Miller (1958) dalam artikelnya yang berjudul "the cost corporation Finance and the theory of investment" mengemukakan nilai suatu perusahaan akan meningkat seiring meningkatnya DER karena adanya pengaruh dari corporate tax rate shield. Hal ini disebabkan karena dalam keadaan pasar sempurna dan adanya pajak, bunga dibayarkan akibat penggunaan hutang dapat digunakan untuk mengurangi penghasilan yang disebabkan adanya pajak atau disebut tax deductible, maka apabila 2 perusahaan yang memperoleh laba operasi yang sama tetapi yang satu menggunakan hutang dan membayar bunga sedangkan perusahaan yang lain tidak, maka perusahaan yang membayar bunga akan membayar pajak penghasilan yang lebih kecil. Karena menghemat membayar pajak merupakan manfaat bagi pemilik perusahaan, maka nilai perusahaan yang menggunakan hutang akan lebih besar dari nilai perusahaan yang tidak menggunakan hutang.

Namun pendapat M\&M yang menunjukkan bahwa perusahaan dapat meningkatkan nilainya bila menggunakan hutang sebesar-besarnya (dalam keadaan kena pajak) ini mengandung kritik dan keberatan dari para praktisi. Keberatan tersebut disebabkan oleh asumsi yang digunakan M\&M dalam analisis mereka, yaitu pasar modal yang sempurna. Adanya ketidak sempurnaan pasar modal menyebabkan pemilik perusahaan atau pemegang saham mungkin keberatan untuk menggunakan leverage yang ekstrim karena akan menurunkan nilai perusahaan. Apabila pasar modal tidak sempurna, kemungkinan antara lain munculnya biaya kebangkrutan, biaya keagenan atau adanya informasi asimetris (Husnan, 1998).

Kecenderungan perusahaan yang makin banyak menggunakan hutang, tanpa disadari secara berangsur-angsur, akan menimbulkan kewajiban yang makin berat bagi perusahaan saat harus melunasi (membayar kembali) hutang tersebut. Tidak jarang perusahaan-perusahaan yang akhirnya tidak mampu memenuhi kewajiban tersebut, dan bahkan dinyatakan pailit.

Penggunaan kebijakan hutang bisa digunakan untuk menciptakan nilai perusahaan yang diinginkan, namun kebijakan hutang juga tergantung dari pertumbuhan perusahaan yang juga terkait dengan ukuran perusahaan. Artinya perusahaan yang besar dan memiliki tingkat pertumbuhan perusahaan yang baik relative lebih mudah untuk mengakses ke pasar modal.

Kemudahan ini mengindikasikan bahwa perusahaan besar relatif mudah memenuhi sumber dana dari hutang melalui pasar modal, perusahaan yang memiliki tingkat pertumbuhan perusahaan yang baik menunjukkan kemampuan perusahaan untuk membayar bunga hutang jika menggunakan hutang untuk menjalankan operasional perusahaan tersebut.Oleh karena itu, mengkaitkan struktur 
modal dengan pertumbuhan perusahaan dan nilai perusahaan menjadi relevan.

Ukuran perusahaan bisa dijadikan acuan untuk menilai kemungkinan kegagalan perusahaan seperti:

a) Biaya kebangkrutan adalah fungsi yang membatasi nilai perusahaan;

b) Perusahaan-perusahaan besar biasanya lebih suka melakukan diversifikasi dibandingkan dengan perusahaan-perusahaan kecil, dan memiliki kemungkinan untuk bangkrut lebih kecil.

Maka pernyataan ini bisa dijadikan sebagai petunjuk bahwa semakin besar ukuran perusahaan (size), akan memberikan kemungkinan bagi perusahaan untuk memiliki hutang yang semakin besar / tinggi pula

Berdasarkan Balance Theory yang dikemukakan oleh (Myers, 1984) dalam Brigham \& Houston (2011) perusahaan mendasarkan diri pada keputusan suatu struktur modal yang optimal. Struktur modal optimal dibentuk dengan menyeimbangkan keuntungan dari penghematan pajak atas penggunaaan hutang terhadap biaya kebangkrutan.

Pecking Order Theory mengatakan bahwa perusahaan lebih cenderung memilih pendanaan yang berasal dari internal dari pada eksternal perusahaan. Penggunaan dana internal lebih didahulukan dibandingkan dengan penggunaan dana yang bersumber dari eksternal. Urut-urutan yang dikemukakan oleh teori ini dalam hal pendanaan adalah pertama laba ditahan diikuti dengan penggunaan hutang dan yang terakhir adalah penerbitan ekuitas baru (Myers, 1984). Pemilihan urutan pendataan ini menunjukkan bahwa pendanaan ini didasarkan dari tingkat cost of fund dari sumber-sumber tersebut yang juga berkaitan dengan tingkat resiko suatu investasi.

\section{Rumusan Masalah}

Berdasarkan latar belakang masalah, maka perumusan masalah adalah apakah terdapat pengaruh besaran perusahaan terhadap struktur modal yang akan berdampak pada nilai perusahaan manufaktur yang terdaftar di Bursa Efek Indonesia tahun 2009 - 2011?

\section{III.Hipotesis.}

H1 : Terdapat pengaruh ukuran perusahaan terhadap struktur modal yang berdampak pada kebijakan nilai perusahaan

\section{Kerangka Pemikiran.}

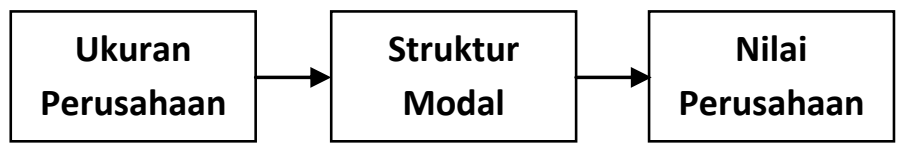

\section{Tinajuan Pustaka}

\section{Hubungan Ukuran Perusahaan Terhadap Struktur Modal}

Menurut Brigham dan Houston (2011:40), perusahaan yang tumbuh dengan pesat harus lebih banyak mengandalkan modal eksternal. Biaya pengembangan untuk penjualan saham biasa lebih besar daripada biaya untuk penerbitan surat hutang yang mendorong perusahaan untuk lebih banyak mengandalkan hutang Perusahaan kecil akan cenderung untuk biaya modal sendiri dan biaya hutang jangka panjang lebih mahal dari pada perusahaan besar. Maka perusahaan kecil akan cenderung menyukai hutang jangka pendek dari pada hutang jangka panjang karena biayanya lebih rendah. 
Demikian juga dengan perusahaan besar akan cenderung memiliki sumber pendanaan yang kuat. Dengan demikian ukuran perusahaan akan memiliki pengaruh terhadap struktur modal.

\section{Hubungan Struktur Modal terhadap Nilai Perusahaan}

Teori trade-off dari Modigliani dan Miller (MM) (1963) menjelaskan bahwa (dengan asumsi titik target struktur modal belum optimum) peningkatan rasio hutang pada struktur modal akan meningkatkan nilai perusahaan sebesar tarif pajak dikali dengan jumlah hutang trade-off theory memprediksi adanya hubungan yang positif terhadap nilai perusahaan

\section{Metode Penelitian.}

\section{Sampel Data.}

Jumlah sampel yang digunakan dalam penelitian ini diambil pada periode laporan keuangan tahun 2009 sampai dengan Juni 2011 pada segmen industri manufaktur yang berjumlah 22 perusahaan di Bursa Efek Indonesia. Periode tahun 2009-2011

\section{Indikator dan Pengukuran Variabel.}

- Ukuran Perusahaan Ukuran perusahaan dalam penelitian ini dihitung dengan diproxy dengan nilai logaritma dari total asset. (Ln Total Asset)

- Struktur modal merupakan perbandingan total hutang yang dimiliki perusahaan terhadap total ekuitas perusahaan. Struktur Modal diukur dengan Debt to Equity Ratio (DER). Debt to Equity Ratio adalah suatu upaya untuk memperlihatkan, dalam format lain, proporsi relatif dari klaim pemberi pinjaman terhadap hak kepemilikan, dan digunakan sebagai ukuran peranan hutang

$$
\text { DER }=\frac{\text { Total Debt }}{\text { Total Equity }}
$$

- Nilai perusahaan diukur dengan Market to Book Value Ratio (MBV). Market to Book Value Ratio adalah perbandingan antara harga pasar perlembar saham terhadap nilai nominal ekuitas perlembar saham (Brigham and Gapenski, 1988: 780).

$$
M B V=\frac{\text { Market value }}{\text { Book value }}
$$

\section{Metode Analisis.}

Metode analisis yang digunakan dalam penelitian ini adalah menggunakan analisis jalur untuk pemecahan masalah regresi dengan variabel intervening.

\section{Pengujian Hipotesis dan Pembahasan.}

\section{Pengujian Hipotesis}

\begin{tabular}{|c|c|c|c|c|c|c|}
\hline \multirow{2}{*}{\multicolumn{2}{|c|}{ Model }} & \multicolumn{2}{|c|}{$\begin{array}{c}\text { Unstandardized } \\
\text { Coefficients }\end{array}$} & \multirow{2}{*}{$\begin{array}{c}\begin{array}{c}\text { Standardize } \\
\mathrm{d} \\
\text { Coefficients }\end{array} \\
\text { Beta }\end{array}$} & \multirow[t]{2}{*}{$\mathrm{t}$} & \multirow[t]{2}{*}{ Sig. } \\
\hline & & $B$ & Std. Error & & & \\
\hline & (Constant) & 1.599 & 4.207 & & .380 & .705 \\
\hline 1 & $\begin{array}{l}\text { Ukuran } \\
\text { Perusahaan }\end{array}$ & .020 & .285 & .009 & .069 & .945 \\
\hline
\end{tabular}

\section{Coefficients $^{\mathrm{a}}$}

a. Dependent Variable: Struktur Modal 


\section{Coefficients $^{\mathrm{a}}$}

\begin{tabular}{|c|c|c|c|c|c|c|}
\hline \multirow{2}{*}{\multicolumn{2}{|c|}{ Model }} & \multicolumn{2}{|c|}{$\begin{array}{l}\text { Unstandardized } \\
\text { Coefficients }\end{array}$} & \multirow{2}{*}{$\begin{array}{c}\begin{array}{c}\text { Standardize } \\
\mathrm{d} \\
\text { Coefficients }\end{array} \\
\text { Beta }\end{array}$} & \multirow[t]{2}{*}{$\mathrm{t}$} & \multirow[t]{2}{*}{ Sig. } \\
\hline & & B & Std. Error & & & \\
\hline \multirow{2}{*}{1} & (Constant) & 1.316 & .210 & & 6.257 & .000 \\
\hline & $\begin{array}{l}\text { Struktur } \\
\text { Modal }\end{array}$ & .247 & .039 & .620 & 6.319 & .000 \\
\hline
\end{tabular}

a. Dependent Variable: Nilai Perusahaan

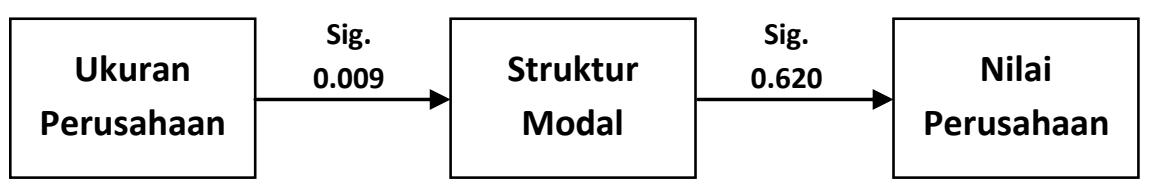

Berdasarkan hasil analisis, dapat diketahui bahwa :

1. Ukuran perusahaan tidak berpengaruh signifikan terhadap struktur modal, nilai korelasi 0.009 yang mengindikasikan tidak mempunyai hubungan yang sangat kuat antara ukuran perusahaan dan nilai perusahaan, dan memiliki persamaan $\mathrm{SM}=1.599+020 \mathrm{UP}$.

2. Struktur Modal berpengaruh signifikan terhadap Nilai Perusahaan, nilai korelasi 0.620 yang mengindikasikan adanya hubungan yang kuat antara Struktur Modal dan Nilai Perusahaan, dan memiliki persamaan $\mathrm{NP}=1.316+0.247 \mathrm{SM}$.

\section{Pembahasan}

Ukuran Perusahaan tidak mempengaruhi struktur modal Hal ini disebabkan walaupun besaran perusahaan tidak besar namun karena perusahaan tersebut merupakan anggota group bisnis tertentu, maka perusahaan tersebut memiliki akses ke sumber pembiayaan eksternal yang lebih baik dari perusahaan besar yang tidak bernaung dalam suatu group bisnis. suatu group yang terdapat anak perusahaan yang bergerak dibidang pembiayaan atau perbankan. Sehingga sangat mudah bagi perusahaan pembiayaan atau perbankan tersebut mengucurkan dana pada perusahaan dalam group yang sama. Pada kondisi ini maka besaran perusahaan tidak signifikan mempengaruhi akses ke sumber pembiayaan. Sehingga perusahaan dengan ukuran yang kecil dapat memiliki akses yang lebih baik dari perusahaan dengan ukuran besar. Dalam kondisi ini, respon pasar yang positip akan lebih berpihak pada perusahaan kecil bukan perusahaan besar. Jadi pasar akan lebih melihat pada kemampuan suatu perusahaan dalam mendapatkan sumber pembiayaan internal ketika dibutuhkan perusahaan, ketimbang pada besaran perusahaan tersebut. Hal ini akan menyebabkan besaran perusahaan tidak signifikan mempengaruhi struktur modal.

Teori trade-off menjelaskan bahwa (dengan asumsi titik target struktur modal belum optimum) peningkatan rasio hutang pada struktur modal akan meningkatkan nilai perusahaan sebesar tarif pajak dikali dengan jumlah hutang Hasil penelitian ini konsisten dengan temuan Modigliani and Miller pada tahun 1963 bahwa dengan memasukkan pajak penghasilan perusahaan, maka penggunaan hutang akan meningkatkan nilai perusahaan 


\section{Kesimpulan.}

Ukuran perusahaan manufaktur tidak mempengaruhi struktur modal. pasar akan lebih melihat pada kemampuan suatu perusahaan dalam mendapatkan sumber pembiayaan internal ketika dibutuhkan perusahaan, ketimbang pada besaran perusahaan tersebut Penelitian ini menunjukkan bahwa adanya pengaruh yang signifikan untuk struktur modal dan nilai perusahaan manufaktur diindonesia sesuai dengan trade off theory (asumsi titik target struktur modal belum optimum)

\section{Daftar Pustaka}

Archer and D'ambrosio, 1976 The theory of business finance Macmillan Publishing Co.Inc

Brigham, E dan Joel F. Houston. 2006. Fundamentals Of Financial Management (Dasar-dasar manajemen keuangan). Terjemahan Ali Akbar Yulianto. Jakarta: Salemba Empat.

Dumas Lusangaji dan Andarwati, 2013 Pengaruh Ukuran Perusahaan, Struktur Aktiva, Pertumbuhan Perusahaan, Dan Profitabilitas Terhadap Struktur Modal http: jimfeb.ub.ac.id

Franco Modigliani and Merton H. Miller, The American Economic Review, Vol. 48, No. 3 (Jun., 1958), pp. 261-297 penerbit American Economic Association

Stewart C. Myers 1984, Capital Structure Puzzle, NBER Working Paper July. 